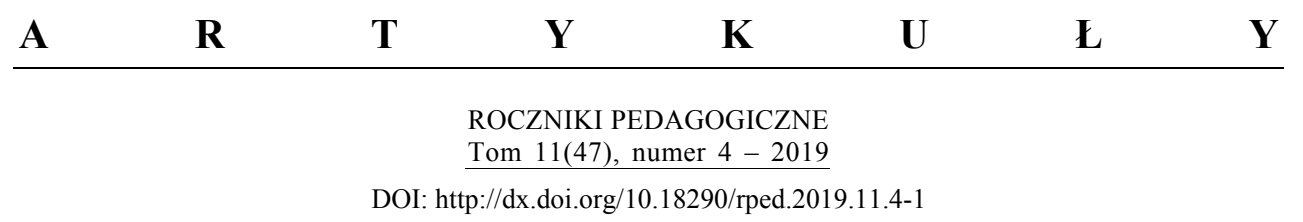

\title{
PRAWOŚĆ - ZAPOMNIANA CNOTA. GŁOS W KWESTII REPRODUKCJI PRAWOŚCI W STRUKTURZE CHARAKTERU I OSOBOWOŚCI MŁODEGO POKOLENIA
}

\section{WPROWADZENIE}

Wartości moralne trudno przecenić. Na temat ich niebagatelnego znaczenia w ludzkim życiu wypowiedział się między innymi Dietrich von Hildebrand, który twierdzi, iż są najistotniejsze spośród wszystkich wartości naturalnych. Dobro, czystość, poszanowanie prawdy i pokora stoją ponad geniuszem, mądrością, [...] zdrowiem, stoją wyżej niż piękno natury i sztuki, niż ład i siła państwa. To, co się dokonuje [...] w akcie szczerego przebaczenia, wielkodusznego wyrzeczenia lub w akcie bezinteresownej żarliwej miłości jest bardziej znaczące [...] i trwalsze od wszelkich wartości tkwiących w kulturze. Wartości moralne są węzłowe [...]; brak moralnych wartości jest największym złem, gorszym niż cierpienie, choroba, śmierć, gorszym niż upadek kwitnących kultur [...]. Uznawały to wszystkie wielkie umysły z Sokratesem i Platonem na czele, powtarzając, że lepiej krzywdy doznać niż ją wyrządzać. Wysuwanie rzeczywistości moralnej na pierwsze miejsce jest również fundamentalną zasadą chrześcijaństwa (Hildebrand, 1982, s. 10).

Do wartości moralnych, które sprawiają, że człowiek może zrealizować się także w perspektywie transcendentnej, czyli osiągnięcia ostatecznego celu swego życia, należy właśnie prawość (Podstawka, 2016, s. 889). Pozostaje ona niezmiennie również cechą konstytuującą człowieka. Choć stanowi rdzenną kategorię deontologii, relatywnie rzadko staje się przedmiotem badań przedstawicieli

Dr hab. AlıCıA ŻYwCZOK - pedagog i filozof; Wydział Nauk Społecznych Uniwersytetu Śląskiego, Instytut Pedagogiki, 40-126 Katowice, ul. Michała Grażyńskiego 53; adres do korespondencji - e-mail: alicjazyw@wp.pl; ORCID: https://orcid.org/0000-0003-3994-9558. 
nauk humanistycznych i społecznych. Zupełnie niezrozumiała jest nieobecność prac monograficznych z tego zakresu między innymi w pedagogice, psychologii oraz socjologii. Ów brak bądź niedostatek monografii naukowych mogą nieznacznie zniwelować artykuły, w których przedmiotem eksploracji są szczegółowe zagadnienia ( $\mathrm{w}$ ramach szerszych badań dotyczących ludzkiej prawości). Zdecydowałam się więc wyjść naprzeciw zapotrzebowaniu w nauce na tę zarazem humanistyczną i społeczną problematykę, a niniejszy tekst stanowi próbę udzielenia odpowiedzi na kilka pytań badawczych:

- Jak przejawia się prawość w ludzkim zachowaniu (zwłaszcza czynach)?

- Na jakiej podstawie daje się rozpoznać (zdiagnozować) symetryczne przeciwieństwo prawości - nieprawość oraz wyodrębnić odmiany nieprawości?

- Na czym polega wychowanie do reprezentowania prawości w rodzinnym środowisku wychowującym?

- Jak za pośrednictwem procesu wychowania dokonać internalizacji normy „bądź prawy”, a także interioryzacji prawości (jako wartości) w strukturze charakteru $^{1}$ oraz osobowości ${ }^{2}$ dzieci i młodzieży?

Odwołując się do aktualnego stanu wiedzy z zakresu pedagogiki i nauk pokrewnych, w treści niniejszego artykułu zaakcentuję znaczenie interdyscyplinarnej kategorii prawości dla rozwoju pedagogiki. Oprócz wyjaśnień leksykalnych przeanalizuję naukowe ujęcie prawości jako między innymi: cnoty ${ }^{3}$

\footnotetext{
${ }^{1}$ Charakter - struktura syntetyczna, kształtująca się w trzeciej fazie rozwoju podłoża socjalnego w psychice człowieka. Powstaje ona ze scalenia czynników temperamentalnych, uczuciowych oraz intelektualnych (inteligencji) wokół wspólnej i skierowanej ku wartościom woli. Funkcją charakteru jest doprowadzenie do dojrzałego postępowania w granicach późniejszego rozwoju świadomości społecznej, opartej głównie na czynnikach wolitywnych (Kunowski, 1946, s. 43; por. Nowak, 2008, s. 394-396).

${ }^{2}$ Osobowość - struktura, do której zmierzają procesy rozwoju człowieka na podłożu kulturalnym. Do jej specyfiki należy wyczuwanie wartości oraz pierwiastek duchowy. Funkcją osobowości człowieka jest wypracowanie postępowania opartego na poczuciu własnej osoby, swej istotności, przeżywającej wartości kulturalne, a nie jedynie społeczne. Osobowość (utożsamiana ze sferą duchową człowieka) stanowi rezultat dynamicznego procesu rozwoju ukierunkowanego na realizację wartości moralnych (Kunowski, 1946, s. 43; por. Nowak, 2008, s. 540).

${ }^{3}$ Cnota (gr. arete - „to, co najlepsze”, łac. virtus) - cecha osobowa człowieka; czynnik wewnętrzny usprawniający do realizacji dobra moralnego; trwała dyspozycja do właściwego działania; rodzaj sprawności, dzięki której postępuje się należycie pod względem moralnym (sprawność moralna). Początkowo arete oznaczało cechy pożądane ludzi poszczególnych stanów, na przykład w wojowniku ceniono męstwo, zręczność, natomiast pożądanymi cnotami rolnika była wytrwałość, cierpliwość, pracowitość. Przeobrażenia polityczne w starożytnej Grecji spowodowały, że cnoty zaczęły oznaczać cechy dobrego obywatela, by z czasem stać się ogólnym określeniem cech człowieka żyjącego możliwie jak najlepiej. Tak pojmowana cnota stała się podstawową kategorią etyki starożytnej (zwłaszcza Platona, Arystotelesa, św. Tomasza z Akwinu). Oprócz cnót chrześcijańskich kardynalnych: wiary, nadziei i miłości, wylicza się jako cnoty moralne także: roztropność, sprawiedliwość, męstwo,
} 
(zbiorczej, to znaczy takiej, którą współtworzą cnoty szczegółowe, na przykład sprawiedliwość, dobroć, prawdomówność, dzielność, uczciwość), dyspozycji (cechy charakteru), normy (bądź zasady postępowania), powinności moralnej, postawy moralnej, a także jako wzorca, wzoru osobowego, celu wychowania, komponentu ideału wychowania, budulca autorytetu pedagogicznego. Ukażę przejawy prawości (istotne w rozwoju diagnostyki pedagogicznej), jej przeciwieństwa (typy nieprawości) oraz specyfikę procesu wychowania człowieka prawego, zwłaszcza w rodzinnym środowisku wychowującym.

Posłużenie się metodami hermeneutycznymi (Grondin, 2007) w badaniu problematyki prawości wydaje się uzasadnione, biorąc pod uwagę konieczność jej pogłębionego poznania.

\section{1. „PRAWOŚĆ”, „PRAWY” - UŚCIŚLENIA LEKSYKALNE}

Wieloznaczność terminu „prawość” w języku polskim wymaga od naukowców zajmujących się fenomenem prawości dokonania trafnego wyboru jednego spośród kilku sposobów pojmowania go, a zatem także sprecyzowania treści i zakresu tego pojęcia. Analiza złożonej semantycznie prawości prowadzi do wyodrębnienia prawości stanowiącej przedmiot zaprezentowanych badań. Pomijając na razie etyczne i pedagogiczne pojmowanie prawości, należy choć śladowo zaznaczyć, że treść pojęcia „prawy” dotyczy:

- strony ludzkiego ciała bądź jego części (na przykład prawa noga, prawe oko);

- strony bądź pozycji danej rzeczy (na przykład prawa strona ulicy, prawy brzeg rzeki, prawa burta);

- ciosu zadanego prawą ręką (na przykład prawy prosty, prawy sierpowy);

- człowieka pomocnego, współpracownika, wspólnika, zastępcę (na przykład nazywając go swą ,prawą ręką");

- człowieka postępującego zgodnie z prawem, legalnie (na przykład prawy spadkobierca) (Inny stownik języka polskiego PWN. P-Ż, 2017, s. 256; Mały stownik języka polskiego, 1968, s. 628).

$\mathrm{W}$ niniejszym artykule nie skorzystam $\mathrm{z}$ podanych wyżej wariantów pojmowania prawości, co najwyżej z ostatniego - piątego dotyczącego zgodności

umiarkowanie. W czasach nowożytnych pojęcie cnoty przestało odgrywać znaczącą rolę w etyce, przypisując mu raczej znaczenie wychowawcze. We współczesnej filozofii moralnej (cnota jako wzorcowa dyspozycja) i teologii moralnej (cnota jako jakość władz duszy) pojęcie cnoty znów staje się kluczowym pojęciem etycznym (Stownik przewodnik filozoficzny. Osoby - problemy - terminy, 2012, s. 373; Jaśtal, 2015, s. 20, 25). 
z prawem jako podstawowym warunkiem prawości, choć zdarza się, że niezgodność z prawem bądź domaganie się modyfikacji wadliwego prawa wyraźniej świadczą o prawości, niż bezrefleksyjne posłuszeństwo literze prawa.

W Etyce nikomachejskiej Arystoteles twierdzi, że do prawości, jako dyspozycji ludzkiej, należy korektura niedomagającego, to znaczy niedoskonałego prawa (Arystoteles, 2007). Prawość będąca cechą charakteru człowieka, niejako wdrukowaną dzięki prawu naturalnemu, wymusza na prawodawcy stałe korygowanie prawa stanowionego. Usilne dążenie do odczucia zgodności między osądem etycznym (określanym mianem sumienia) a wyrokami prawa zdaje się świadczyć o prawości charakteru danego człowieka. Filozof pisze: „Człowiekiem prawym jest [...] mianowicie ten, kto takie czyny postanawia i takich zwykł dokonywać i kto nie obstaje uparcie przy swoim prawie na niekorzyść drugiego, lecz pozwala się ukrucić [skarcić - A.Ż.], nawet wtedy gdy ma prawo po swojej stronie; trwała dyspozycja do takiego postępowania jest prawością" (Arystoteles, 2007, s. 189).

Prawo, które nie dość dokładnie uwzględnia subtelność indywidualnego sumienia i złożoność problemów moralnych wymaga zmiany, a konstruktywność tejże zmiany mogą gwarantować jedynie ludzie prawi. Demokratyczny ład społeczny nie jest uzależniony od jakichkolwiek decyzji zbiorowych/gremialnych, ale od rozważnych decyzji prawej większości. Nie stanowi więc nadużycia, jak sądzę, twierdzenie, że podstawą utrzymania demokracji jest taka cecha ludzka, jak prawość. $Z$ wielu powodów warto zatem poznawać ją, propagować i rozwijać w młodym pokoleniu. $Z$ piątym wariantem pojmowania prawości wiążą się inne jeszcze terminy pokrewne semantycznie, takie jak: „praworządny”, „prawomocny” oraz „prawowity”, których użyteczności w podjętej problematyce nie kwestionuję. Terminy te okazują się jednak niewystarczające, by naświetlić istotę prawości moralnej.

W niniejszym artykule posłużę się terminem „prawy” przede wszystkim odnośnie do:

- czynu prawego jako spełnienia powinności moralnej (bądź obowiązku moralnego, zobowiązania moralnego) (Kant, 2015, s. 32);

- życia prawego polegającego nie tylko na spełnianiu norm etycznych czy religijnych, lecz także na stałym dążeniu do wewnętrznej przemiany i poprawy (Fromm, 2000, s. 47);

- człowieka odznaczającego się licznymi zaletami charakteru; postępującego uczciwie, szlachetnie (o którym mówi się zazwyczaj, że „idzie prawą drogą” bądź „kroczy drogą prawości”). 
W języku odzwierciedla się rzeczywistość znacząca dla człowieka żyjącego w danym okresie dziejów. Rzadsze niż niegdyś posługiwanie się tym terminem nie jest jedynie znakiem czasów, ale niepokojącym przejawem zagrożeń moralnych. Trudno bowiem zastąpić prawość innym terminem równie istotnym i wskazującym dokładnie ten sam komponent człowieczeństwa, któremu przypisano nazwę ,prawość”. Rugowanie z języka tak fundamentalnych dla satysfakcjonującego życia moralnego terminów, jak „prawość”, może skutkować inercją w sferze moralnej bądź opóźnieniem rozwoju moralnego dzieci i młodzieży. Warto więc reaktywować ten termin zarówno w językowych formach wypowiedzi, jak i praktykować cechę oraz postawę prawości w rodzinie oraz $\mathrm{w}$ innych środowiskach wychowujących. Stałe odtwarzanie, odradzanie się (reprodukcja) tej cechy gwarantuje odpowiedni przekaz międzypokoleniowy cnót (cech typowo ludzkich), decydujących nie tyle o przetrwaniu człowieka, ile o odpowiedniej jakości jego życia moralnego.

\section{JAK ROZPOZNAĆ CZŁOWIEKA PRAWEGO WŚRÓD NIEPRAWYCH, CZYLI O GŁÓWNYCH PRZEJAWACH PRAWOŚCI}

Nie zważając na etyczną i logiczną trudność zadania - diagnozy prawości, w zachowaniu człowieka prawego daje się zauważyć pewne prawidłowości. Prawidłowości te umożliwiają wyodrębnienie przejawów bądź ich klas składających się na symptomy wyróżniające ludzi prawych. Do przejawów tych należą:

- otwartość na wartości i ideały moralne, na konstruktywne wzorce postępowania, wzory osobowe, a także na wartościowy styl życia;

- gotowość podporządkowania się wartościom moralnym i duchowym (na przykład respekt wobec prawdy, wymogów sprawiedliwości czy pokoju) oraz konsekwentnej ich obrony;

- chętne/ochocze odpowiadanie na konstruktywną ofertę wartości moralnych, społecznych bądź duchowych godnym reprezentowaniem tych grup wartości;

- zachowywanie ostrożności asymilując nowe idee i przekonania; poświęcanie czasu i uwagi argumentacji merytorycznej i rozważeniu wielu faktów;

- spójny system wartości (inaczej - właściwa hierarchia wartości) deklarowanych i realizowanych (przeciwieństwo oportunizmu);

- dojrzałość emocjonalna, uczuciowa (rozpoznawane między innymi dzięki empatii) i społeczna (rozpoznawana między innymi za pośrednictwem obserwacji inicjatyw altruistycznych); 
- sprawność w identyfikacji ewidentnego zła bądź zagrożeń dobra moralnego;

- stanowcze sprzeciwianie się czyjejś krzywdzie (na przykład człowieka, zwierzęcia, środowiska przyrodniczego) i dostrzeżonej niesprawiedliwości (reagowanie niezgodą na wszelkie zło, na przykład na próbę zachwiania ładu społecznego, zerwania bądź osłabienia więzi międzyludzkich, rozbicia jedności wspólnot, takich jak rodzina czy grupa wyznaniowa, i na redukowanie solidarności w innych środowiskach, choćby w szkole, stowarzyszeniu, klubie);

- niechęć wobec powierzchownej i nieobiektywnej oceny czyjegoś czynu, zachowania, postępowania, czyjejś decyzji, relacji, postawy, biografii, stylu życia itd.;

- niehołdowanie stereotypom, niezatajanie prawdy, nieupowszechnianie kłamstw, niedopuszczanie do stronniczości czy krzywoprzysięstwa, unikanie obmowy i plotkowania (Żywczok, 2016; Żywczok, 2017);

- opór wobec wpływu czynników dezintegracyjnych bądź destruktywnych, takich jak niekorzystna presja społeczna (choćby negatywny nacisk grupy w sytuacji leczenia uzależnień lub nakłanianie kogoś do nagannego postępowania za cenę dostępu do korzyści materialnych, władzy, sławy i innych profitów) czy manipulacja (jak w przypadku indoktrynacji);

- dążenie do konsensusu w relacjach interpersonalnych (choćby rozwiązując konflikty za pośrednictwem na przykład doskonalenia umiejętności przebaczania i pojednania, docenienia stanu zgody i pokoju);

- pragnienie rozwoju integralnego siebie i innych ludzi (dążenie do samorealizacji bądź pomocy innym w samorealizacji etycznej, moralnej, supererogacyjnej, religijnej, uczuciowej, emocjonalnej, intelektualnej);

- stała tendencja do modyfikowania swego zachowania, do przemiany wewnętrznej i ukierunkowania swego życia na realizację celów nie tylko doraźnych, lecz również eschatologicznych;

- rezygnacja $\mathrm{z}$ dochodzenia swoich praw $\mathrm{w}$ imię osiągnięcia wyższych wartości. Ludzie prawi różnią się od jedynie sprawiedliwych tym, że potrafią obdarowywać innych bardziej niż wymagałoby tego poczucie sprawiedliwości.

Zaproponowany i zaprezentowany wyżej katalog przejawów prawości może przypominać charakterystykę człowieka, któremu przypisano atrybut bądź postawę godności. Porównaniu cech człowieka prawego i człowieka godziwego oraz ukazaniu subtelnej różnicy między człowiekiem godziwym (bądź reprezentującym postawę godności) i człowiekiem prawym zostanie poświęcona kolejna publikacja. W tym tekście natomiast prezentacja przejawów ludzkiej prawości powinna służyć rozwojowi diagnostyki pedagogicznej i terapii przeciwieństw prawości - różnych odmian nieprawości dezorganizujących prawidłowy proces wychowania moralnego. 


\section{NIEPRAWOŚĆ - ZAGRAŻAJĄCE WSPÓŁCZESNYM LUDZIOM PRZECIWIEŃSTWO PRAWOŚCI I JEGO TYPY}

Antonimem terminu ,prawość” jest „nieprawość”, zatem symetrycznym przeciwieństwem człowieka prawego pozostaje „człowiek nieprawy”. Przyjmując, że prawość stanowi cnotę ugruntowaną w tradycji kultury („cnota staropolska”) i opisywaną już w historiografii średniowiecznej, jej przeciwieństwo - nieprawość była terminem także wówczas powszechnie używanym.

Jako przykład niech posłuży fragment dzieła kronikarza i biskupa krakowskiego Wincentego Kadłubka, który charakteryzując w XII wieku człowieka nieprawego pisze: „Cokolwiek było w nim dzielności, pochłonęła ją przepaść występków; cokolwiek było szczodrobliwości, zdmuchnęła ją żądza sławy" (Mistrz Wincenty Kadłubek, 1996, s. 80). Nieco później Andrzej Frycz Modrzewski - analizując rękojmie, jakie winny dawać prawa - podaje: „Powinny zatem prawa utrzymywać każdego w jego obowiązkach; odciąć możność szkodzenia innym; poskramiać zuchwalstwo ludzi niepoczciwych, uczynić całkowicie bezpieczną niewinność każdego, jak najmocniej troszczyć się o pokój i godność ludzi uczciwych [...], strzec spokojnego trwania Rzeczypospolitej” (Frycz Modrzewski, 2003, s. 137).

$\mathrm{Na}$ temat przeciwieństw prawości wypowiedział się również współczesny uczony Dietrich von Hildebrand. Wyodrębnił on (przyjmując jako kryterium przyczynę) dwa typy nieprawości:

- Pierwszy: rodzący się z pychy. Odnośnie do tego typu człowieka nieprawego filozof pisze: ,[...] nieprawy [...] człowiek jest niezdolny do poświęceń i podporządkowania się [...]. Jest niewolnikiem pychy, owego egoizmu, który zasklepia go w sobie i zamyka mu oczy na to, co jest wartością, nieustannie narzucając mu pytanie: «czy przez to wzrośnie moje znaczenie?», «czy podniesie to mój prestiż?». Podchodzi do wszystkiego z zarozumiałością, poczuciem urojonej wyższości i zupełnie nie zadaje sobie trudu zrozumienia jakiejś sprawy do głębi [...]. W jego [...] cynicznym spojrzeniu świat zostaje zmiażdżony do jednego wymiaru [...], przechodzi obok świata wartości, zupełnie go nie zauważając [...]. Atakuje wszystko w tak [...] nietaktowny sposób, że widzi i słyszy tylko samego siebie, zupełnie nie dostrzegając tego, co istnieje poza nim" (Hildebrand, 1982, s. 13-14).

- Drugi: powstający wskutek pożądliwości. Ten typ nieprawości dostarcza opisu człowieka - niewolnika pożądliwości, „wskutek której wydaje mu się, że cały świat istnieje po to, aby on miał okazję osiągnięcia przyjemności. Interesuje 
go tylko to, czy coś [...] zapewni mu pożytek. Widzi we wszystkim tylko wycinek mający związek z jego [...] bezpośrednim interesem [...]. Toteż człowiek nieprawy nie ma nigdy wewnętrznej ciszy [wewnętrznego spokoju - A.Ż.] (Tamże).

Wypowiedzi Hildebranda pozwalają dostrzec zasadniczą przyczynę czynów nieprawych, która tkwi w przywarach ludzkiego charakteru. Pycha oraz pożądliwość (chciwość, zachłanność) tworzą podatny grunt do rozwoju licznych przeciwieństw prawości zarówno wśród dzieci, młodzieży, jak i dorosłych.

Odnośnie do rugowania nieprawości Wincenty Kadłubek zaleca wyznanie i w ten sposób ujawnienie nieprawego postępowania w celu jego usprawiedliwienia. Do kwestii tej Mistrz ustosunkował się następująco: „Zmazać gdy chcesz nieprawość, ukaż otwarcie przewinę. Winy się bowiem wyzbywa, kto z płaczem wyznaje winę. Czyni cię winnym pogrzebana wina, odkryta wyzwala. Skóra ściśnięta żywi zakałę, otwarta wydala" (Mistrz Wincenty Kadłubek, 1996, s. 80).

Przeciwieństwa prawości nie stanowią jednak zasadniczej problematyki niniejszego artykułu, mogą wszak okazać się pomocne jako klaryfikacja skomplikowanych kwestii związanych z nakreśleniem specyfiki ,prawego charakteru” oraz „prawego postępowania”. Na tle przeciwieństw prawości i destrukcji, jaką powodują, łatwiej zaakcentować udział ludzi prawych w normalizacji oraz modyfikowaniu różnych obszarów życia społecznego, choćby prawodawstwa, gospodarki, polityki. Nie należy pomijać przy tym kwestii pedagogicznych, ponieważ dopiero odpowiedni proces wychowania człowieka tworzy właściwe warunki do rozwoju cnoty prawości. Formacja wychowawcza znacząco zasila bowiem sferę prawodawstwa, gospodarki oraz polityki.

\section{RODZINNE WYCHOWANIE DO REPREZENTOWANIA POSTAWY PRAWOŚCI - REFLEKSJE PRAKSEOLOGICZNE}

Nie należy do ryzykownych twierdzenie, iż problematyka prawości nie została w pedagogice odpowiednio rozpoznana badawczo: opisana i wyjaśniona. Treść pojęcia prawości sugeruje, iż „prawość” należy do podstawowych kategorii takich subdyscyplin pedagogicznych, jak teoria wychowania czy pedagogika ogólna. W dorobku naukowym wyliczonych subdyscyplin daje się dostrzec, niestety, zaledwie ślady intencjonalnego nawiązania do terminu ,prawość”. Znacznie częściej można w nim odnaleźć inne terminy, choćby „godność” czy „sprawiedliwość". Niezwykle rzadkie badanie prawości czyni ją kategorią atrakcyjną 
zwłaszcza dla teoretyków wychowania moralnego i pedagogów ogólnych oraz pozwala uznać za oryginalny przedmiot badań w tych subdyscyplinach. Problematyka ta powinna jednak budzić zainteresowanie również reprezentantów pedagogiki rodziny, pedagogiki szkolnej, pedeutologii, pedagogiki społecznej oraz andragogiki, w których prawość podlegałaby eksploracji zarówno jako dezyderat teoretyczny, jak i praktyczny. Odniesienie prawości do wielu podmiotów: wychowujących dzieci i młodzież w rodzinie (na przykład rodziców, opiekunów, dziadków, starszego rodzeństwa); wspierających rodzinę (między innymi asystentów rodzin, kuratorów sądowych, pracowników socjalnych, duszpasterzy, terapeutów rodzin); oraz podmiotów wychowywanych (na przykład potomstwa, podopiecznych, rodzeństwa, wnucząt) z pewnością uzupełniłoby stan wiedzy pedagogicznej w tym zakresie.

Integralne wychowanie (zob. Nowak, Ożóg, Rynio, red., 2003; Opozda, red., 2015; Opiela, Braun, red., 2017) do uosabiania prawości okazuje się jednym z najistotniejszych postulatów antropologicznych i pedagogicznych. Ukształtowanie człowieka prawego staje się bowiem naczelnym celem wychowawców realizujących proces wychowania moralnego dzieci i młodzieży. Cel ten, choć przyświecał zwłaszcza przedstawicielom minionych pokoleń, wciąż nie traci na znaczeniu. Istotne, by nie zakwalifikować go do reliktów przeszłości i nie uznać za anachroniczny. Taka cecha charakteru, jak prawość, choć współtworzy ideał wychowania (będąc jego składnikiem), nie powinna być uznawana za pozostającą w sferze odległych idei, lecz postrzegana jako współczesna oferta edukacyjna wzbogacająca osobowość człowieka oraz mająca istotne znaczenie noetyczne. Trudno zaprzeczyć temu, że czynnikiem budującym autorytet moralny danego człowieka (w tym rodzica, dziadka/babci, brata/siostry) jest właśnie jego prawość. Cecha ta predystynuje również do przewodzenia grupom, reprezentowania większości w życiu publicznym oraz pozostawania wyrazicielem ich woli.

Nie ulega wątpliwości, że odpowiednie relacje i postawy najbliższych członków rodziny macierzystej stanowią dla młodego pokolenia „pierwowzór” prawości. Mimo tego, że w przedszkolu czy szkole dzieci spędzają sporą część czasu w ciągu dnia, rodzina pozostaje na ogół pierwotnym środowiskiem jego rozwoju i „kuźnią” takich cech, jak prawość (bądź niestety jej przeciwieństwa nieprawości).

Prawi rodzice, którzy otwarcie wyrażają swój stosunek do istotnych kwestii publicznych, ujawniając jednoznacznie dezaprobatę wobec oportunizmu, manipulacji, nepotyzmu, protekcjonizmu, korupcji, pomówień i innych zagrożeń społecznych, są najlepszymi „wychowawcami prawości”. Dzieci, obserwujące 
ojca lub matkę odważnie reagujących na akty niesprawiedliwości bezinteresowną pomocą bądź obroną grup tak zwanych nieuprzywilejowanych: skrzywdzonych przez prawo, prześladowanych politycznie, doznających mobbingu bądź stalkingu szkolnego czy zawodowego, poszkodowanych w wyniku klęsk, kataklizmów, katastrof, wyzyskiwanych, zaniedbywanych pod względem biosocjokulturowym itp., otrzymują w rodzinie największy naturalny kapitał w postaci wzorca postępowania, z którego będą korzystać w okresie dorosłości. Nie godząc się (i nie zezwalając) ani na czyjąś krzywdę, ani też na własne poczucie skrzywdzenia, przyczyniają się do zwiększenia $\mathrm{w}$ społeczeństwie liczby ludzi prawych, co nie pozostaje bez znaczenia dla harmonijnego życia zbiorowego. Oczekując od każdego środowiska (między innymi przedszkola, szkoły, internatu, ośrodka kultury) respektowania zasad poszanowania godności człowieka, równości, sprawiedliwości, oraz domagając się przestrzegania relacji i procedur demokratycznych, wykazują swym dzieciom, że aktywność i zaangażowanie przynoszą pożądane rezultaty, rodzą optymistyczny stosunek do rozwiązywania problemów i konfliktów oraz wyjaśniania nieporozumień. Uczą też, że warto zwracać się po pomoc bądź korzystać ze wsparcia zwłaszcza ludzi prawych. Rozmawiając z dziećmi, rodzice odwołujący się w swej argumentacji do normy moralnej nakazu: „bądź prawy” i normy moralnej zakazu: „unikaj czynienia nieprawości” (,nie postępuj niegodziwie”), przyjmują właściwy kierunek wychowawczy i profilaktyczny.

Za najtrwalszą lokatę człowieczeństwa można uznać więc nie zabezpieczenie finansowe, ale międzypokoleniowy przekaz w postaci czynnej postawy personalistycznej, w której zaznacza się wyraźnie służba i przychylność ludziom, subtelne poczucie sprawiedliwości, praworządność, dzielność etyczna i wyrozumiałość. Rodzice, którzy powstrzymują się od podsycania w dzieciach wrogości wobec innych ludzi, lecz rozumieją, że warto od najwcześniejszego okresu kształtować w potomstwu umiejętność nawiązywania i utrzymywania pozytywnych relacji koleżeńskich i przyjacielskich, przekazują mu największe zasoby humanistyczne w postaci dóbr moralnych. Uzdalniają ich w ten sposób do „uczuć wyższych” (związanych także z uczuciami religijnymi): głębokiej i trwałej miłości, empatii, wierności, wdzięczności i odpowiedzialności, mimo iż niektóre z tych cech/cnót uważa się dziś za anachroniczne bądź niekonieczne. Rodzice, niepoddający się współczesnym zagrożeniom materializmu, konsumpcjonizmu czy egoizmu, tworzą swemu potomstwu właściwe warunki do rozwoju uczciwości, wielkoduszności, wspaniałomyślności, altruizmu - postaw będących podwaliną prawości.

$\mathrm{Na}$ uwagę zasługuje $\mathrm{w}$ tym zakresie postawa prawości również wśród rodzeństwa. Rodzeństwo zazwyczaj przejmuje i uosabia postawy rodziców, lecz 
zdarzają się przypadki, kiedy wbrew wzorcowi postępowania nieprawych rodziców, starsza siostra bądź brat sprawuje opiekę nad młodszym rodzeństwem, dzielnie niwelując niedostatki pieczy rodzicielskiej. Trud związany $\mathrm{z}$ uwewnętrznieniem właściwych wartości i zbudowaniem odpowiedniej ich hierarchii jest wówczas znacznie większy, lecz skutek takich starań nie jest przesądzony. Prawość ludzka rzadko wynika bowiem z łatwości egzystencjalnej, a częściej z przezwyciężenia wielu przeszkód, cierpienia, z docenienia zwyczajnego procesu życiowego czy dostrzeżenia sensu w skomplikowanych kolejach losu.

Całokształt wychowawczej formacji rodzinnej decyduje o pełnieniu ról społecznych w sposób prawy. Chyba nigdy tak wyraźnie jak dziś nie zaznaczył się społeczny popyt na prawych małżonków, rodziców, pracowników, uczniów, studentów. I chyba nigdy przedstawiciele pedagogiki rodziny nie stali przed tak wielkimi zadaniami, wręcz wyzwaniami związanymi z reprodukcją prawości w strukturze charakteru i osobowości młodego pokolenia. Liczba zagrożeń społecznych przekonuje o konieczności zastosowania równie silnej przeciwwagi w postaci atrakcyjnych ofert i propozycji edukacyjnych (do których można by zaliczyć wychowanie w duchu prawości).

Jako egzemplifikację prakseologicznego zastosowania propozycji wychowania do prawości w rodzinie niech posłuży czytelnictwo biografii ludzi uznawanych powszechnie za prawych. Warto skorzystać z opublikowanych biografii współczesnych świętych i innych prawych ludzi ${ }^{4}$, gdyż obfitują we wzorce postępowania pomocne $\mathrm{w}$ ukierunkowaniu decyzji młodzieży wyłącznie na cele wartościowe. Daje się w nich odszukać wzory prawych członków rodziny; nie tylko rodziców czy rodzeństwa, ale również dziadków, wujostwa, kuzynostwa itd. Ukazane w biografiach losy ludzkie i przykładne metody pokonywania trudności życiowych wzbudzają szacunek, a czasem wdzięczność wobec poprzedników, rodzą pozytywne uczucia sympatii i podziwu, przekonują do wierności wartościom moralnym, do nawiązywania pozytywnych, głębokich i trwałych więzi. Duże zainteresowanie młodzieży wzbudzają na ogół również filmy biograficzne (fabularne i dokumentalne) bądź sztuki teatralne, oglądane (w kinie, teatrze lub $\mathrm{w}$ domu) wspólnie $\mathrm{z}$ rodzicami. Wskazane pod względem wychowawczym i terapeutycznym pozostaje jednak wyrażanie swej kreatywności, przygotowując samodzielnie film bądź pisząc scenariusz sztuki teatralnej upamiętniającej biografię/losy ludzi cenionych w danej społeczności za swą prawość.

\footnotetext{
${ }^{4} \mathrm{Za}$ interesującą propozycję biograficzną może posłużyć sylwetka Jacka Krawczyka (19661991), studenta Katolickiego Uniwersytetu Lubelskiego, który z niezwykłym poświęceniem i bezinteresownością pomagał innym ludziom, choć sam cierpiał na nieuleczalną chorobę nowotworową. Swą chrześcijańską postawą dał świadectwo prawości, miłości bliźniego oraz przyjęcia z godnością w bardzo młodym wieku cierpienia i śmierci (Zob. Derdziuk, 2019).
} 


\section{PODSUMOWANIE}

Uogólnienie wyników niniejszych analiz i refleksji prowadzi do wysunięcia następujących wniosków:

1. Prawość jest wartością o niebagatelnym znaczeniu etycznym, moralnym i społecznym. Jako rdzenna kategoria deontologii i cecha konstytuująca człowieka stanowi zaniedbany, oryginalny przedmiot badań w naukach humanistycznych i społecznych (takich, jak pedagogika).

2. Oprócz etycznego ujęcia prawości jako między innymi: cnoty (zbiorczej), dyspozycji, normy (bądź zasady postępowania) i powinności moralnej, w pedagogice (zwłaszcza w jej subdyscyplinie - teorii wychowania) najistotniejsze okazuje się postrzeganie prawości jako cechy charakteru, powinności moralnej, postawy moralnej, komponentu ideału wychowania, celu wychowania, wzorca postępowania, budulca autorytetu moralnego i pedagogicznego.

3. Reprezentowanie postawy prawości stanowi wyróżnik dobrego rodzica, opiekuna bądź wychowawcy dzieci i młodzieży. Natomiast interioryzacja w młodym pokoleniu takiej wartości, jak prawość oraz internalizacja analizowanej normy moralnej nakazu i zakazu zachodzi za pośrednictwem odpowiedniego procesu wychowania, zwłaszcza w rodzinie, zaś przejawia się w cechach, a także w postawie syna/córki bądź podopiecznego. Postawę prawości można uznać także za naturalne przeciwdziałanie nieprawościom (prewencję nieprawości).

4. Rodzina stanowi pierwotne środowisko wychowujące w duchu prawości, dlatego nie powinno dziwić, że to głównie postawa prawości rodziców determinuje prawość potomstwa. Nie oznacza to jednak, iż deficytów prawości w rodzinie nie udaje się wypełnić innymi wzorami, choćby obcując z przykładnymi członkami innej grupy: stowarzyszenia czy wspólnoty, bądź korzystając z zasobów kultury, na przykład z czytelnictwa opublikowanych biografii ludzi prawych, z projekcji bądź samodzielnego nakręcenia filmu biograficznego czy obejrzenia bądź wykreowania sztuki teatralnej.

\section{BIBLIOGRAFIA}

ARYstoteles (2007). Etyka nikomachejska (tł. D. Gromska). Warszawa: Wydawnictwo Naukowe PWN.

DerdziuK, A. (2019). Człowiek na maksa. Rzeszów: Bonus Liber Wydawnictwo i Drukarnia Diecezji Rzeszowskiej. 
Fromm, E. (2000). Mieć czy być? (tł. J. Karłowski). Poznań: Dom Wydawniczy „Rebis”.

FRYCZ MODRZEWSKI, A. (2003). Wybór pism (oprac. W. Voisé). Wrocław: Zakład Narodowy im. Ossolińskich - Wydawnictwo.

Grondin, J. (2007). Wprowadzenie do hermeneutyki filozoficznej (tł. L. Łysień). Kraków: Wydawnictwo WAM.

Hildebrand, D. (1982). Fundamentalne postawy moralne. Prawość. W: D. Hildebrand, J.A. KŁoczowski, J. PAŚciaK, J. Tischner, Wobec wartości (s. 7-19). Poznań: W drodze.

Inny słownik języka polskiego PWN. P-Ż (2017). M. BAŃKO (red.). Warszawa: Wydawnictwo Naukowe PWN.

JAŚTAL, J. (2015). Etyka i czas. Wariacje aretologiczne. Kraków: „Księgarnia Akademicka”.

KANT, I. (2015). Metafizyka moralności (tł. E. Nowak). Warszawa: Wydawnictwo Naukowe PWN.

KunOwski, S. (1946). Proces wychowawczy i jego struktury: temperament, indywidualność, charakter, osobowość. Zarys teorii. Lublin: Instytut Pracy Nauczycielskiej.

Mały słownik języka polskiego (1968). S. SKORUPKA, H. AUDERSKA, Z. ŁEMPICKA (red.). Warszawa: Państwowe Wydawnictwo Naukowe.

MistRZ WinCENTY KADŁUBEK (1996). Kronika polska (tł. B. Kürbis). Wrocław: Zakład Narodowy im. Ossolińskich.

NowAK, M. (2008). Teorie $i$ koncepcje wychowania. Warszawa: Wydawnictwa Akademickie i Profesjonalne.

NowaK, M., OżóG, T., RYNiO, A. (red.) (2003). W trosce o integralne wychowanie. Lublin: Wydawnictwo Katolickiego Uniwersytetu Lubelskiego.

Opiela, M.L., Braun, K. (red.) (2017). W kręgu integralnego wychowania. Refleksja teologiczno-pedagogiczna. Lublin: Wydawnictwo „Werset”.

OpOzDA, D. (red.) (2015). Rodzina miejscem integralnego rozwoju i wychowania. Lublin: Wydawnictwo „Episteme”.

Podstawka, K. (2016). Prawość. W: K. ChaŁas, A. MaJ (red.), Encyklopedia aksjologii pedagogicznej (s. 885-889). Radom: Polskie Wydawnictwo Encyklopedyczne POLWEN.

Stownik przewodnik filozoficzny. Osoby - problemy - terminy (2012). MARYNIARCZYK, A., JAROSZYŃSKI, P., KIEREŚ, H., ZDYBICKA, Z.J. (red.). Lublin: Polskie Towarzystwo Tomasza z Akwinu.

ŻywCZOK, A. (2016). Wychować człowieka prawdomównego. Koncepcje, badania naukowe, wdrożenia. Katowice: Wydawnictwo Uniwersytetu Śląskiego.

ŻYwCZOK, A. (2017). Kłamstwo - zagrożenie dla trwałości związku małżeńskiego i spójności rodziny. Wychowanie w Rodzinie, 16 (2), 213-226.

\section{PRAWOŚĆ - ZAPOMNIANA CNOTA. \\ GLOS W KWESTII REPRODUKCJI PRAWOŚCI W STRUKTURZE CHARAKTERU I OSOBOWOŚCI MŁODEGO POKOLENIA}

Streszczenie

Autorka artykułu twierdzi, że prawość choć stanowi rdzenną kategorię deontologii i wartość moralną konstytuującą człowieka, relatywnie rzadko staje się przedmiotem badań przedstawicieli nauk humanistycznych i społecznych, takich jak pedagogika. Podjęła się więc eksploracji niektórych zagadnień w ramach szerszych badań dotyczących ludzkiej prawości. Niniejszy tekst stanowi zatem próbę udzielenia odpowiedzi na kilka pytań badawczych: jak przejawia się prawość w ludzkim zachowaniu (zwłaszcza czynach)?; na jakiej podstawie daje się rozpoznać symetryczne przeciwieństwo prawości nieprawość oraz wyodrębnić odmiany nieprawości?; na czym polega wychowanie do reprezentowania prawości w rodzinnym środowisku wychowującym?; jak za pośrednictwem procesu wychowania 
dokonać internalizacji normy „bądź prawy” oraz interioryzacji prawości (jako wartości) w strukturze charakteru oraz osobowości dzieci i młodzieży? Odwołując się do aktualnego stanu wiedzy, Autorka zaakcentowała znaczenie interdyscyplinarnej kategorii prawości dla rozwoju pedagogiki. Oprócz wyjaśnień leksykalnych zaprezentowała naukowe ujęcie prawości jako między innymi: cnoty (zbiorczej), dyspozycji (cechy charakteru), normy (zasady postępowania), powinności moralnej, postawy moralnej, wzorca postępowania, wzoru osobowego, komponentu ideału wychowania, celu wychowania, budulca autorytetu pedagogicznego. Ukazała również istotne w rozwoju diagnostyki pedagogicznej przejawy i przeciwieństwa prawości (typy nieprawości) oraz specyfikę procesu wychowania człowieka prawego, zwłaszcza w środowisku rodzinnym. Posłużenie się metodami hermeneutycznymi w badaniu problematyki prawości okazało się uzasadnione, biorąc pod uwagę konieczność jej pogłębionego poznania.

Słowa kluczowe: prawość; rodzina; cnota moralna; charakter; osobowość.

\author{
RIGHTEOUSNESS - A FORGOTTEN VIRTUE. \\ A VOICE ON THE ISSUE OF REPRODUCTION OF RIGHTEOUSNESS \\ IN THE STRUCTURE OF CHARACTER \\ AND PERSONALITY OF A YOUNG GENERATION
}

\title{
S u m m a r y
}

The author of the article proposes that righteousness, even though itself an essential category of deontology and a moral value that constitutes the human being, is relatively rarely studied by representatives of social and humanistic sciences, such as pedagogics. Hence this paper aims at exploration of some issues within a wider framework of research on human righteousness. It is an attempt to answer the following questions: how does righteousness manifest itself in human behavior (especially in action)?; how can the symmetric opposite of righteousness, i.e. iniquity be recognized?; what kinds of iniquity can be identified?; how is a young person to be brought up in order to represent righteousness in the familial upbringing environment?; how to achieve the internalization of the norm "Be righteous" using the upbringing process?; how can upbringing be used to interiorize righteousness (as a value) in the structure of character and personality of children and the youth? Referring to the current state of knowledge the author emphasizes the significance of the interdisciplinary category of righteousness in the development of pedagogics. Apart from lexical explanations she also presents a scientific concept of righteousness as, among others: a virtue (collective), disposition (character traits), a norm (principles of demeanor), moral obligation, moral attitude, a component of the ideal of upbringing, an aim of upbringing, and a pedagogical building material. The author also presents manifestations and antonyms of righteousness (types of iniquity), significant in the development of pedagogical diagnostics, along with the specific character of the process of upbringing of the righteous human being, especially in the familial environment. Hermeneutic methods were utilized in order to thoroughly examine the studied issues.

Key words: righteousness; family; moral virtue; character; personality. 